PEKPEAUIЙHA TEOTPAФIG

УДК 374:[338.48-6:001.89]

DOI: https://doi.org/10.15407/ugz2019.04.028

\author{
G. I. Denysyk ${ }^{1}$, A. M. Kolomiiets', I. V. Gromov', D. I. Kolomiiets ${ }^{1}$, D. Kamenova ${ }^{2}$ \\ ${ }^{1}$ Vinnytsia Mykhailo Kotsiubynskyi State Pedagogical University, Ukraine \\ ${ }^{2}$ Varna University of Management, Bulgaria
}

\title{
INTERNATIONAL SCIENTIFIC AND PEDAGOGICAL COMMUNICATION AS A CONSTITUENT PART OF THE TOURISM ACTIVITY
}

The authors have analyzed the essence and main characteristics of the scientific tourism phenomenon; defined the presentday tendencies in development of higher education in Europe and Ukraine; first studied the actual proposals from European countries concerning the internship programs for teachers; determined the current situation and potential possibilities of foreign internships for the Ukrainian universities' teachers professional development; outlined the prospects of the scientific tourism development in Ukraine and the perspectives for internship of the foreign colleagues on the basis of Ukrainian universities. It has been mentioned that the new knowledge, information, skills, and experience, acquired during the scientific tours are actively used in the further practical professional activities of the higher school teachers. Therefore, the authors came to the conclusion that the study and use of the progressive European experience will significantly accelerate the approaching the Ukrainian system of professional education to the European standards. It has been also concluded that a considerable number of organizational measures and steps must be undertaken for adequate response to the world-wide trend of students' and teachers' academic migration, as well as for attracting the representatives of the international scientific communities to the Ukrainian higher educational institutions. The main task is to develop promotional events presenting our scientific and educational achievements in the maximally good light. It is also necessary to develop the infrastructure and encourage the activities of institutes, universities, research centers, aimed at the educational and scientific tourism development. The scientific novelty is in determination of the main reasons motivating the higher school teachers to participate in the scientific tourism programs.

Keywords: international scientific and pedagogical communication; foreign internship; international cooperation; scientific tourism.

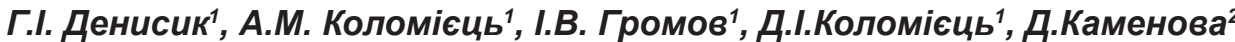 \\ ${ }^{1}$ Вінницький державний педагогічний університет імені Михайла Коцюбинського \\ ²Варненський університет менеджменту, Болгарія}

\section{МІЖНАРОДНА НАУКОВО-ПЕДАГОГІЧНА КОМУНІКАЦІЯ ЯК СКЛАДОВА ТУРИСТИЧНОЇ ДІЯЛЬНОСТІ}

Проаналізовано суть та основні характеристики явища наукового туризму; визначено сучасні тенденції розвитку вищої освіти в Європі та Україні; вперше вивчено фактичні пропозиції європейських країн щодо програм стажування викладачів; визначено сучасну ситуацію та потенційні можливості закордонних стажувань для професійного розвитку викладачів українських університетів; окреслено перспективи розвитку наукового туризму в Україні та перспективи стажування іноземних колег на базі українських університетів. Зазначено, що нові знання, інформація, вміння та досвід, здобуті під час наукових екскурсій, активно використовуються у подальшій практичній професійній діяльності викладачів вищої школи. Тому автори дійшли висновку, що вивчення та використання прогресивного європейського досвіду сприятиме наближенню української системи професійної освіти до європейських стандартів. Також було зроблено висновок про необхідність проведення значної кількості організаційних заходів та заходів для адекватного реагування на світову тенденцію академічної міграції студентів та викладачів, а також для залучення представників міжнародних наукових спільнот до українських вищих навчальних закладів. Основним завданням $є$ розроблення рекламних заходів, що представляють наші наукові та навчальні досягнення в максимально позитивному світлі. Необхідно також розвивати інфраструктуру та заохочувати діяльність інститутів, університетів, науково-дослідних центрів, спрямовану на розвиток освітнього та наукового туризму. Наукова новизна полягає у визначенні основних причин, що мотивують викладачів вищої школи брати участь у наукових програмах туризму.

Ключові слова: міжнародна науково-педагогічна комунікація; зарубіжне стажування; міжнародне співробітництво; науковий туризм.

(c) G. I. Denysyk, A. M. Kolomiiets, I. V. Gromov, D. I. Kolomiiets, D. Kamenova, 2019 


\section{Research topicality}

Nowadays the integration processes cover an increasing number of states. In this regard, the European Union is not only one of the first world's integration associations, but the most successful one. Therefore, in many countries, we observe the growth of scientific and public interest in the phenomenon of European integration, the identification of its essence, and determining the degree of its influence on various spheres of the sovereign states' life, in particular, the sphere of education. This is logical, since education in any country remains the main factor in its sustainable development.

It's a great pity to admit that the present-day level of the national educational system development is lagging behind the growing social needs of the Ukrainian society. The consequence of this lag is resulting in the society's discontent with the outcome of the educational system functioning, which remains largely conservative. Besides, the processes of the society's democratization and humanization come into conflict with the ideological-worldview, and value vacuum in education. This is also accompanied by uncertainty in the education and upbringing goals; penetration of the practically unverified knowledge into the education content; the collapse of the former education system managing mechanisms in the absence of any reliable legislative framework in this area; insufficient level of the state subsidies on education.

After coming into force on 1 September 2017 the ratified Ukraine-European Union Association Agreement, the European integration of Ukraine became unavoidable but at the same time it sets the new challenging tasks for the national education system [1]. The European Union (with its macroeconomic, macro-financial, macro-technological, macro-political, and macro-cultural dimensions) now determines the specifics, dynamics, frontiers, dominants, criteria, and laws of the European labour market, which is the main realization field for an individual involved into the education process. Therefore the European Union becomes a speaker of the objectively necessary and system-forming educational principles, rules and norms.

In Ukraine, like in all European countries, education is also considered a decisive factor in the country's cultural progress and human resource development. Government policy is aimed at joining the European Union. In line with this objective, Ukraine will accept and fully utilize the achievements of European Union's legislation in the field of education and professional training. Ukraine's participation in this process will help to achieve the equal position of the national higher education institutions and specialists not only in the European but also in the world community. It might also solve the problem of the Ukrainian diplomas recognition and strengthening the Ukrainian specialists' positions in the labor market.

Nevertheless, in practice one can observe plenty of contradictions, problems, and even paradoxes in the Ukrainian higher education system. They significantly hamper the process of integration into the European educational and scientific space. Higher education reforms and gradual standardization of the system in accordance with the world trends and European requirements are carried out unpardonably slowly. This happens due to the fact that: various social, economic and political problems intersect and contradict; there is no proper modernization of the professional education system; the existing European experience of professional training isn't fully studied and applied by the native educationalists and practical teachers. Therefore, the intensification of international cooperation between Ukrainian and European higher education institutions is absolutely necessary. We presume that one of the most effective forms of such cooperation is educational and scientific tourism.

\section{Literature Review}

Formation and rapid development of the educational services' international market in the beginning of the XXI century led to the merger of two initially separate branches of economy - education and tourism. A new independent trend has emerged in the tourist services market structure - international educational tourism, the feature of which is mass, and not elitist character.

Educational tourism involves such tourism services and products as different educational programs, student exchange programs, tours, excursions, and various types of tours that have a purpose of the study, and new types of educational tourism-related activities (e.g. ethnic workshops and field study trips). It can be stated that demand for the educational tourism products is enormous since, according to the Organization for Economic Cooperation and Development (OECD), the number of students enrolled in higher education outside their country of citizenship has more than doubled over past decades [2].

Different aspects of the interaction between the 
tourist business and the educational services industry as well as the perspective directions of the world tourism development in the beginning of the Third Millennium are presented in the Ritchie Brent's, Neil Carr's and Chris Cooper's monograph [3] where the main features and positive effects of such interaction have also been analyzed. The scholars state that due to the educational tourism an individual can acquire not only new knowledge and useful experience, but can also improve his (her) professional qualifications, and widen his (her) partnership contacts, simultaneously coming to know the local people culture and habits. The educational tours will allow people to treat each other more respectfully, esteem and appreciate all countries and all cultures. The educational tourism is defined as «a trip of a separate individual or a group of people to a certain region (country, city) in order to receive educational services within specific programs». Obtaining these educational services usually contributes to increasing an individual's value as a specialist at the labour market.

Typically, the following features of educational tourism are distinguished: a trip, during which a traveler acquires knowledge in a certain area; a trip, in which professional education is the main goal; revenues from educational tourism go to support the country's economy; thanks to the educational tourism development new jobs are created; educational tourism is an auxiliary vehicle for the society development.

The useful combination of the study and leisure activities makes the educational tourism more and more in demand. Good business results stimulate the diversity and quality of supply in the international educational services market. Having analyzed such phenomena as international academic mobility, educational and scientific travelling, one may come to the conclusion that international educational tourism is currently developing taking into account the specifics of academic exchange, based on the developed tourism industry infrastructure.

According to O.A. Ageeva's work [4], the educational tourism includes study tours for the purpose of improving foreign languages proficiency or increasing competency in various general disciplines or/and special subjects. It also embraces different familiarization tours to institutions, organizations and enterprises; participation in scientific seminars, conferences, congresses, symposiums, creative workshops and master classes, the purpose of which is the exchange of experience and the acquisition of new professionally important information; sightseeing tours in different cities, natural areas and countries [4]. It is obvious that the foreign internships of higher school teachers can be included here. But, in other scholars' opinion, this kind of internship is rather «scientific» than «educational» tourism.

Generally, the term «scientific tourism» appeared in literature for the first time in the work by Jan G. Laarman and Richard R. Perdue [5], where the term was opposed to an ordinary scientific expedition, and described as «a purposeful work of explorers in other countries without proper technical equipment».

Two years later, in 1982, Morris B. Holbrook and Elizabeth C. Hirschman in the paper [6] made an attempt to consider the phenomenon of scientific tourism from the standpoint of the theory of consumption. The scholars presumed that a "scientific tourist» (researcher, academician, teacher) doesn't simply consume the tourism experience by visiting (individually or within a group) foreign universities, research centers, laboratories, libraries, and other places or events of scientific interest. He (she) also requires that the tourism experience gained, and the specific tourism services associated with it, meet his (her) best expectations. Thus, the «scientific tourist» becomes not only a consumer of cognitive experience, but also an active participant, who can directly influence the organization of the cognition process [6].

The New York Times columnist and a science popularizer Peter Kuyavinskyy in the review [7] determines the scientific tourism as a specific form of tourism that is related to scientific practice and brings benefits not only for science, but also for tourism industry, as the works (articles, reviews, essays etc.), written in various popular scientific journals by the results of such travellings, have not only scientific value, but also actively promote popularization the places (countries, cities, universities) visited by the tourist-researchers. He also reminds that «this type of tourism is generally light on the wallet».

The researchers L. Ilyina and Z. Mieczkowski in their article [8] agree with P. Kujawinski and characterize the scientific tourism as a way of obtaining new knowledge and practical skills without any significant financial expenses.

Several definitions of the scientific tourism are presented in the work by J.H. Liang [9]. According to the scientist, the successful scientific tourism does not only include all the necessary attributes and services residing in so called «ordinary tourism». This type 
of tourism requires a human factor and technical equipment of the high level, raising the increased demands for both the proficiency of the scientific «auxiliary personnel» (guides, lecturers, researchers) and for technical support of the scientific tours.

Magdalen Piklerova holds a similar view, arguing in the article [10] that at the heart of the scientific tourism lies the principle of satisfaction the leisure, cultural and educational needs of an individual or a group of people who are interested in a particular scientific problem. The researcher is convinced that the main components of the successful scientific tourism are, first of all, highly qualified mentors, guides, experts who provide clear and comprehensive explanations on the scientific tour issues, and secondly, well-established tourist and scientific infrastructure, starting with commonplace transfer, accommodation and feeding services, and ending with available modern scientific equipment, software, hardware, and methodological support (including multimedia means, various visualization), as well as representativeness and accessibility of the proposed courses, programs, excursions, etc.

Lucia Molokacova and Stefan Molokac in their paper [11] promote the idea that, like all other types of travellers, the scientific tourists utilize the usual tourist infrastructure (hotels, restaurants, bars, transport, cultural events, relaxation and recreation centers), as well as the most advanced audiovisual and computer technological means for conducting lectures, classes, seminars. Among the scientific tourists, beside the «elite» academic researchers, there may often be found usual teachers, educators, graduate students and postgraduates who are interested in international internship programs. These scientific tourists actively use the acquired new knowledge, skills, and information in their further practical professional activities, so in this way, scientific tourism acquires the features of the educational tourism.

In our opinion, the most universal and precise definition of the scientific tourism is offered by Fabien Burlon and Robinson Torres in the presentation [12]. The scholars note that the scientific tourism is a kind of «niche» within other alternative forms of tourism that shares specificities of learning, cultural, leisure, recreational, adventure, and experimental tourism, but has wider implications and benefits. It is described as a tourism that generates and distributes acquired impressions, experiences, pleasures, knowledge and skills through publications (reviews, reports, articles).
Therefore the scientific tourism is more productive and attractive when compared to many traditional forms of tourism.

As one can see, almost 40 years have elapsed since the term's appearance, but the phenomenon of scientific tourism has not still received a generally approved official definition and, according to various scientific sources, may acquire different interpretations. Having analyzed the most common variants, we came to the conclusion that all of them anyhow define the scientific tourism as a kind of ordinary tourism, carried out in accordance with a specific scientific task related to data collection, research, training, participation in scientific events (conferences, seminars, symposiums), gaining new knowledge, increasing the level of the researcher's scientific competence, etc. That is, this category includes any organized science-oriented actions taking place on the territory of a foreign state.

So, the main feature of the scientific tourism is the orientation towards deliberate gaining new knowledge. The main its forms are foreign tours aiming at: conducting experimental research; collecting materials and samples; visiting scientifically important places and objects (natural and anthropogenic monuments, museums, establishments, research centers, laboratories, observatories, universities, enterprises etc.); exchanging experience through participation in the scientific forums (conferences, symposiums, seminars, etc.); improving the scientists' practical skills through training within scientific programs, projects, courses, summer and winter scientific schools, camps, etc. The last form of the scientific tourism can be distinguished in a separate type of tourism - the so-called «educational tourism».

Recently, many professional researchers, even world-wide-renowned scholars, have become interested in proposals for the scientific tourism. These scientists are attracted by the leading foreign scientific centers conducting research in the spheres of science, different from their major scientific specialization. Thus, sometimes a well-known physicist for a short time becomes a biologistsbeginner, a venerable paleontologist turns into an astronomer, and a guru of medicine acts as a pedagogical college student. And this is being done not for entertainment. This is a quick and effective way to study the new techniques, technologies, methods, auxiliary means and supplementary equipment, which the scientists are likely to use in 
conducting further researches within the framework of their major scientific specializations [10]. Hence, the scientific tourism is gaining in popularity, and therefore this phenomenon deserves a separate study.

$\mathrm{Th}$ e a i $\mathrm{m}$ of the article is to determine the present-day capabilities and the further possibilities of the scientific tourism for increasing the Ukrainian higher school teachers' professional level as well as to outline the perspectives of the Ukrainian universities in the sphere of organizing the scientific tourism programs for the foreign colleagues.

\section{Methods of the research.}

The theoretical basis of the study are the provisions concerning the nature and organizational features of the scientific tourism in Europe [2,3, 5-10, 12 and others]. While conducting the study the authors used the following research methods: descriptive analysis of the definitions and the essence of the scientific tourism concept; comparative analysis of the educational and scientific tourism in Ukraine and abroad; quantitative and qualitative analysis of the actual proposals of the EU countries regarding the academic internships programs for high school teachers; analysis of a new European teacher's function spectrum expansion; observation the teachers' professional activities in conditions of European integration; questioning teachers about the factors influencing the scientific internship place choice; forecasting the possible scientific tourism opportunities for foreign colleagues in Ukraine.

To ensure the survey results reliability, first of all we determined the sample size. Since at the beginning of 2019 the overall amount of teachers in the Ukrainian pedagogical universities equaled to about 6500 , we had to find out how many teachers need to be interrogated. It had been done to ensure the fact that, with a probability of 0.95 , it could be stated that the awareness of the need for foreign internships within the sample group differs not more than 0.05 from the same the awareness within the general amount of teachers. We calculated it using the following formula:

$$
n=\frac{N t^{2} p q}{N \Delta^{2}+t^{2} p q}
$$

where $N$ - overall amount of teachers, $p$ and $q$ - quantity of teachers who are aware or aren't aware of the need for foreign internships, $\Delta=0.05, t=1.96$ - determined from the tables for $F(t)=0.95$ [13]

Since the quantities of the teachers who are aware $(p)$, and the teachers who aren't aware $(q)$ of the need for foreign internships, are unknown, one should take their values to make their product maximal, i.e. $p \times q=0.25$. Having substituted the corresponding values in the formula, we got $n \approx 377$. So, to form a representative sample, we decided to interrogate the participants of ten international and all-Ukrainian scientific conferences that were held on the basis of the Vinnytsia Mykhailo Kotsiubynskyi State Pedagogical University January through May 2019. The sample embraced higher school teachers of various disciplines (specialties), who represented pedagogical universities of the most Ukrainian regions.

\section{Discussion and Results}

The survey covered 395 respondents. In our opinion this sample must have shown the real picture concerning the visited countries and the factors which motivated the respondents to participation in foreign internships. Among the mentioned factors there were: wish for seeing the ways of living in other countries, wish for studying foreign experience in the field of education, getting acquainted with the current trends in pedagogical education development, necessity of obtaining an internship certificate, wish for changing the routine situation and have some rest, opportunity of spending more time with colleagues in informal setting, coercion from the side of governing bodies, wish for getting acquainted with the newest technical equipment, need for establishing international contacts, wish for stay in a foreign-language environment, need for scientific research, need for professional self-improvement within the internship topics, and others.

We chose the most frequently mentioned factors and tried to evaluate their importance. To determine the priority factors encouraging teachers to take part in the foreign internships, we applied the expert evaluation method [14]. The expert group included those teachers who had participated in three or more foreign internships within three last years. There were 32 such respondents (among the group of 395). The proposed questionnaires included 9 major factors and were evaluated by the experts on a five-point scale according to the following criteria: «decisive» -5 points, «very important» -4 points, «important» -3 points, «little significant» -2 points, «insignificant» -1 point. The results of the statistic processing of the factors' expert evaluation are presented in the table 1. 
Results of the expert evaluation of the priority factors encouraging teachers

Table 1.

to take part in the foreign internships

\begin{tabular}{|c|c|c|c|c|c|c|c|c|}
\hline $\begin{array}{l}\text { Factors } \\
\text { encouraging teachers to take part in the foreign } \\
\text { internships }\end{array}$ & $\mathrm{X}$ mean & $\sigma$ & Q & $\begin{array}{l}\mathrm{RX} \\
\text { mean }\end{array}$ & $\mathrm{R} \sigma$ & RQ & $\sum \mathrm{R}$ & $\mathrm{R}$ \\
\hline $\begin{array}{l}\text { Possibility to increase the level of professional } \\
\text { competency }\end{array}$ & 3.55 & 1.05 & 0.72 & 5 & 4 & 7 & 16 & 5 \\
\hline $\begin{array}{l}\text { Wish for stay in a foreign-language } \\
\text { professional and cultural environment }\end{array}$ & 3.10 & 1.09 & 0.74 & 8 & 5 & 8 & 21 & 7 \\
\hline Coercion from the side of governing bodies & 3.00 & 2.26 & 0.84 & 9 & 9 & 9 & 27 & 9 \\
\hline $\begin{array}{l}\text { Wish for changing the routine work situation } \\
\text { and spending time with colleagues in different } \\
\text { professional and cultural environment }\end{array}$ & 4.15 & 1.20 & 0.56 & 3 & 7 & 3 & 13 & 4 \\
\hline $\begin{array}{l}\text { Wish for studying foreign experience of the } \\
\text { higher education organization }\end{array}$ & 4.45 & 0.667 & 0.298 & 2 & 1 & 1 & 4 & 1 \\
\hline $\begin{array}{l}\text { Need for establishing international academic } \\
\text { and scientific contacts }\end{array}$ & 3.40 & 1.15 & 0.68 & 6 & 6 & 5 & 17 & 6 \\
\hline $\begin{array}{l}\text { Necessity of obtaining a foreign internship } \\
\text { certificate }\end{array}$ & 3.80 & 0.71 & 0.58 & 4 & 3 & 4 & 11 & 3 \\
\hline Wish for visiting a tourist attractive country & 4.50 & 0.67 & 0.30 & 1 & 2 & 2 & 5 & 2 \\
\hline The internship topics evoke great interest & 3.30 & 1.26 & 0.69 & 7 & 8 & 6 & 21 & 8 \\
\hline
\end{tabular}

$\mathrm{X}_{\text {mean }}$ - mean value of the factors' importance degree evaluation;

$\sigma$ - dispersion;

$\mathrm{Q}$ - tolerance interval;

$\mathrm{RX}_{\text {mean }}-\mathrm{X}$ mean-index rate;

$\mathrm{R} \sigma-\sigma$-index rate;

$\mathrm{RQ}$ - Q-index rate;

$\Sigma \mathrm{R}-$ sum of all indices' rates;

$\mathrm{R}$ - factors resulting rate.

The values of $\mathrm{X}_{\text {mean }}, \sigma$, and $\mathrm{Q}$ for each of the nine factors were calculated using the following formulas:

$$
\begin{aligned}
& X_{\text {mein }}=\frac{\sum x_{i}}{n} \\
& \sigma=\sqrt{\frac{\sum\left(x_{i}-x_{\text {meth }}\right)^{2} \cdot n_{i}}{n}} \\
& Q=X_{\text {minu }} \pm \frac{2 \sigma}{\sqrt{n}}
\end{aligned}
$$

Dispersion $(\sigma)$ - deviation of the partial values and single experts' opinions from the mean value $\left(\mathrm{X}_{\text {mean }}\right)$, showing how much the experts' opinions are coordinated concerning a particular factor. Consequently, the smaller the dispersion value, the more stable the average result is. In mathematical statistics (including pedagogical statistics methods) there is a need to determine a certain method's error. In pedagogical studies the accepted level of a method's error is accepted up to five-percent significance. Such evaluation of representativeness is carried out using the tolerance interval (Q). In our measurement the tolerance interval shows the scope within which the mean value of a certain factor may variate depending on the observations quantity in every concrete case. Thus, on the basis of the statistic results processing, the group of experts determined the factors which may be characterized as «decisive» or «very important». These are the factors having the importance degree $\left(\mathrm{X}_{\text {mean }}\right)$ value higher than 3.5. They are:

1) wish for studying foreign experience of the higher education organization;

2) wish for visiting a tourist attractive country;

3) necessity of obtaining a foreign internship certificate;

4) wish for changing the routine work situation and spending time with colleagues in different professional and cultural environment;

5) possibility to increase the level of professional competency.

It is not difficult to notice that by its motivational influence the factor of a country's tourist attractiveness is placed second after the factor of studying foreign 
experience, and is even more decisive than the necessity of obtaining a foreign internship certificate. In its turn the wish for changing the routine work situation and spending time with colleagues in different professional and cultural environment surpasses the possibility to increase the level of professional competency and the need for establishing international academic and scientific contacts. This means that the countries possessing high tourist potential can also make use of the scientific tourism events, including foreign internships for teachers and scientists. Organizing the scientific tourism events during the low season period will increase the hotels and restaurants profitability, as well as can promote the further popularization of tourist sites among the academic community.

Like in other European countries, the necessity of accelerating the pace of the Ukrainian professional education system modernization is evoked by the modern features and trends of the country's economic, political, and social development. Among the main trends there are: new social requirements, causing changes in the paradigm of teachers' training, retraining and internship; reorientation from the massreproductive to the individual-creative approach in education; accelerating obsolescence of the gained knowledge; constant expansion the spheres of the gained knowledge application; humanization and democratization of the educational system; creation and development the system of continuous (lifelong) education; gradual integration into the World and European cultural space; need in improving the humanitarian, psychological and pedagogical training of the higher education institutions' pedagogical staff; need of the higher education institutions in pedagogical staff possessing not only a high level of academic knowledge, but also creative activity, readiness for development and self-development, initiative and responsibility; need of the society in a new type of teacher able not only to train a future specialist but also bring up a competitive personality.

All these trends evoked the significant changes in a higher school teacher's functions. From a retranslator of knowledge, he becomes a moderator of the learning environment, which helps each student in building not only an individual learning tactic, but also his life strategy. A modern higher school teacher of the United Europe acts as: a methodologist, possessing the profound knowledge in the field of theoretical bases for the present-day methodological approaches to the educational process organization; a researcher, actively participating in the process of modernization of the social-educational system, understanding the most urgent problems, and (on the basis of critical thinking and reflections) looking for the best ways of their solving; an innovator, generating original ideas, elaborating the new education techniques, and implementing the innovative pedagogical methods into practice; a partner, building relationships with the colleagues and students on the bases of partnership, cooperation, and mutual respect; a manager, supervising the students' project activities, and conducting teaching of the basis of personal approach; a creator, forming and developing the students' competencies necessary for effective and safe living in the contemporary globalized world; a tutor, accompanying a student in the process of individual learning, and participating in elaboration of the personalized educational programs for his students; a coach, revealing the possibilities for every student's abilities and talents development.

The classical system of university education is world-wide known for its conservatism. But in Ukraine, like in many other post-Soviet states, the higher education system still continues taking away (layer after layer) the rust of the communist past. Now we are growing up in our independence. We're fully aware of the fact that higher education, research, and pedagogical innovations play a crucial role in supporting social cohesion, economic growth and competitiveness in the modern «society of knowledge». Therefore, in the context of European integration, the analysis of problems in the Ukrainian higher education system, and searching the ways of their solution, taking into account the positive experience of European countries, is relevant. This is what the Ukrainian universities are eager to do, persistently activating the moves in the field of international cooperation.

The rapid accumulation of new knowledge requires development of international cooperation in the field of education and science, aimed at expanding the citizens' possibility of gaining access to education not only within their own state, but also in foreign countries. To achieve this goal, it is necessary to increase the students' and teachers' mobility, including regular internships, academic exchange, and different international events of scientific character (congresses, conferences, etc.). 
Active participation in the international academic mobility has become an integral part of the European scientific community life. The Law of Ukraine «On Higher Education» aims at including Ukraine into the global, in particular European, academic space. The intensity of the international academic mobility has become an indicator of success and recognition. Now it is considered as a merit of both a separate scientific (pedagogical) worker, and the university as a whole. Participation in international programs is included in the ranking system of the most European universities and is a mandatory point in the system of evaluation of the higher education institutions teaching staff's professional competency [15].

As a matter of fact, in Ukraine the academic mobility is presented mainly in the form of the educational tourism. Every year, more and more Ukrainian students join full or partial undergraduate programs (courses) in the European Union countries. At the same time, the majority of the Ukrainian universities' teaching staff, as practice shows, does not show any sufficient activity in the direction of participation in the scientific tourism.

In Ukraine, the main feature of the scientific tourism is recognized as active participation of a tourist in the scientific tour process, and not just travelling, sightseeing, acquisition of curious information and contemplation various objects and places, which is typical for usual cognitive tourism. Among the types of scientific tourism there are: ecological tours, ethno-cultural expeditions, familiarization with science, industry, agriculture, and technology achievements, participation in the scientific congresses, symposiums, seminars. Typically, different nature reserves, national parks, anthropogenic and nature monuments, and other protected areas stand for the tourist objects in the scientific tours.

In our opinion, when it comes to the higher school teachers' foreign internships, we mostly deal exactly with the scientific tourism, since its main purpose is to expand the scientific and pedagogical outlook of the participants, to exchange scientific and professional information, to participate in scientific events. Very often writing of a scientific publication (article, essay, book, and monograph) is demanded as a compulsory result of the foreign internship. Scientific tourism of the higher school teachers contributes to the new scientific ideas emergence, expansion of the scientific and educational relations between different countries, launch of international projects etc.

The scientific tourism also brings significant income to a hosting country economy. This is primarily due to the foreign currency revenues. In addition, a tourist always remains a tourist (even in a business trip) he buys souvenirs, visits excursions, restaurants, etc. Therefore, the scientific tourism (foreign internships, international practices, conferences, symposiums, etc.) together with the educational tourism (students academic mobility) are now of the most promising and highly profitable branches of the tourist industry. Their share in the international tourist exchange in recent years has increased significantly [2].

According to available estimates, participants of the international scientific events account for $6 \%$ to $7 \%$ of the total number of the foreign visitors, and they account for about $10 \%$ of foreign currency earnings from the general amount of tourists. However, not only the scientific tourism's economic role contributes to its attractiveness. It facilitates the establishment of new effective contacts between the representatives of world intellectual elite, regardless of the geopolitical or social status of each individual traveler. The scientific internships help to enhance the image of scientific and educational institutions which both organize and participate in such events.

The significant influence of teachers' foreign internship on improving their professionalism, individual indicators of their scientific activity, and the institution image as a whole has evoked the rapid increase in promoting this business direction in Ukraine over the past three years. An analysis of the Ukrainian pedagogical universities rectors' reports showed that only in 2018, an average of $15 \%$ to $20 \%$ of the teaching staff participated in the foreign internship programs. In particular, in 2018-2019 academic year, out of 397 teachers of Vinnytsia Mykhailo Kotsiubynskyi State Pedagogical University, 104 teachers (26.2\%) took part in the internships in various, mostly European, countries. In general, during 2016-2019 academic years, 185 our colleagues became the scientific tourists.

It is quite obvious that practical implementation of these international relations and contacts, especially organizing visits of students and teachers to foreign institutions and participation in internships, must contribute to the Ukrainian universities' improvement. These trips should be guided, first of all, by the usefulness for the national system of education and science. At the same time, the programs participants 
Statistics of the actual offers from the European countries concerning the scientific internship programs, including educational internships (April 2019)

\begin{tabular}{|c|c|c|c|c|c|}
\hline Country & $\begin{array}{l}\text { Overall quantity } \\
\text { of internship } \\
\text { programs }\end{array}$ & $\begin{array}{c}\text { Quantity of } \\
\text { educational } \\
\text { internship programs }\end{array}$ & Country & $\begin{array}{l}\text { Overall quantity } \\
\text { of internship } \\
\text { programs }\end{array}$ & $\begin{array}{c}\text { Quantity of } \\
\text { educational } \\
\text { internship programs }\end{array}$ \\
\hline Austria & 15 & 5 & Ireland & 71 & 25 \\
\hline Belgium & 8 & 6 & Italy & 55 & 30 \\
\hline Bosnia & 5 & 1 & Latvia & 10 & 3 \\
\hline Bulgaria & 11 & 4 & Malta & 8 & 3 \\
\hline Croatia & 5 & 1 & Moldova & 5 & 1 \\
\hline Czech & 36 & 9 & Netherlands & 13 & 3 \\
\hline Denmark & 4 & 1 & Norway & 10 & 2 \\
\hline UK & 98 & 35 & Poland & 7 & 2 \\
\hline Estonia & 11 & 3 & Portugal & 20 & 9 \\
\hline Finland & 10 & 3 & Romania & 9 & 4 \\
\hline France & 41 & 18 & Russia & 16 & 7 \\
\hline Germany & 39 & 15 & Spain & 169 & 55 \\
\hline Greece & 21 & 6 & Sweden & 5 & 1 \\
\hline Hungary & 5 & 1 & Switzerland & 13 & 2 \\
\hline Iceland & 3 & 1 & Ukraine & 4 & 1 \\
\hline
\end{tabular}

must improve their preparation for foreign internships, especially polishing up their foreign language proficiency. The universities must also introduce an effective reporting system on a scientific trip results. The purpose of such report is familiarizing the university staff with the main ideas, tendencies, and peculiarities of the European higher education system organization, analysis of its advantages to the total number of internship programs offered is 25-30 percent (Table 2).

However, among the offers aimed at teachers from the post-Soviet countries (like Ukraine), the championship palm is confidently held by Poland, Germany, Slovakia, Bulgaria and Czech. The distribution of the internships number by countries (for Vinnytsia Mykhailo Kotsiubynskyi State

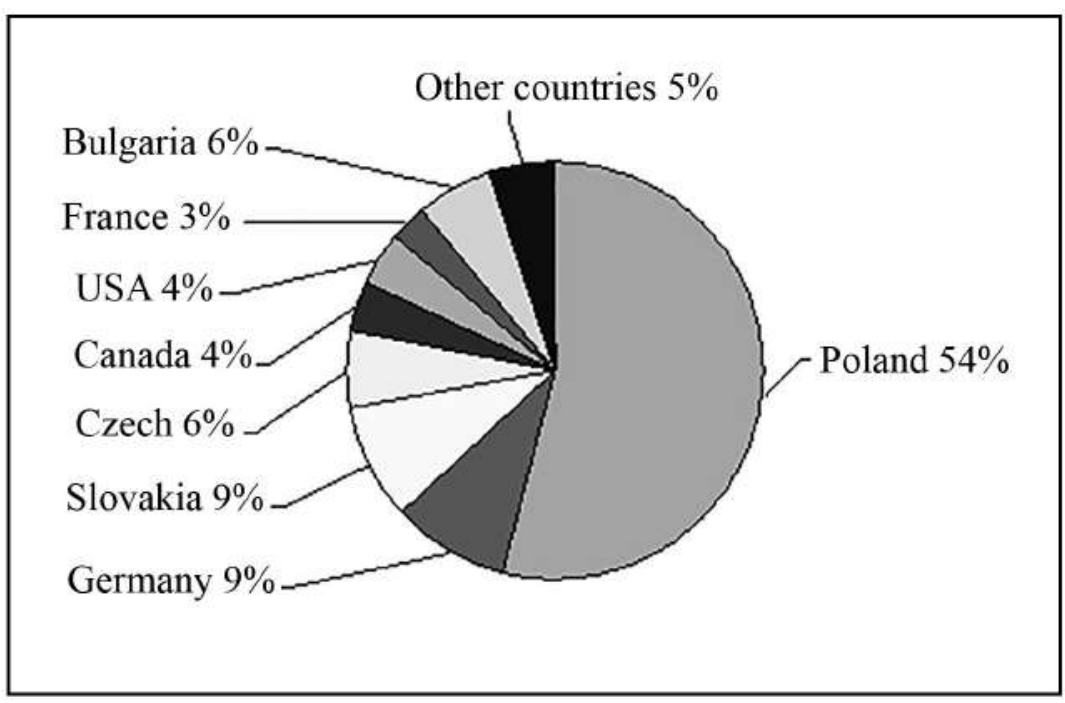

Fig. 1. Geographical distribution of teachers' foreign internships in 20162019 academic years or disadvantages, and making decisions concerning what foreign experience should be implemented on the territory of Ukraine.

Having analyzed the scientific internships promotional offers, presented by the popular European educational portals Go-Overseas. com (https://www.gooverseas. com/internships-abroad/europe) and Go-Abroad.com (https: /www. goabroad.com/intern-abroad), we determined that the leading positions in this segment hold such countries as Spain, Great Britain, Ireland, Italy, France, Germany, Czech Republic. Moreover, the ratio of the educational programs number 
Pedagogical University employees) has the form presented below (Figure 1).

The main conclusions made by teachers after taking part in the foreign internships were as follows:

- the European universities' curricula are designed to meet the students' needs and the modern society demands;

- the European universities create the most comfortable conditions for all the students, in particular for people with disabilities; the exact sciences' educational laboratories are equipped with the most modern instruments for scientific research;

- the innovative pedagogical technologies are widely used in the educational process;

- project activities of students are preferable among other education activities.

Thanks to the communication of the higher school teachers from different countries, one can observe the effect of equalizing the levels of awareness in many spheres of modern pedagogical science, in particular, the achievements in the field of innovative pedagogy. This practice contributes greatly to the creation of the special socio-psychological reality - an international pedagogical partnership.

Among the most important conclusion made by the Ukrainian higher school teachers is that the Ukrainian universities and research institutions also have scientific and educational achievements which are worth sharing among the foreign colleagues. That's why we are sure that a deep analysis of the scientific tourism development in the European Union countries is a topical direction for the further investigations which will enable determination of the similar perspectives of development of the scientific tourism in Ukraine, for example, the possibilities for scientific internships of the colleagues from abroad on the basis of Ukrainian higher schools.

In addition, the colleagues note that in order to enrich professional experience it is necessary to expand the diversity of countries where the scientific internship may be provided. To determine the main factors of attractiveness for various scientific and pedagogical tours, we analyzed the topics of seminars, living conditions, transfer peculiarities, cultural programs and the general price policy of certain educational programs. Using the survey method, we found out which of the mentioned factors may become a decisive reason for choosing one or another place for the foreign internship.
Having analyzed the internship proposals, one can make sure of the offered programs topicality. The programs' content is relevant for both the practical teachers and the educationalists. Among the proposed seminars the most interesting are those related to: internationalization of the educational process at universities; academic mobility of teachers and students; innovative methods and technologies in the educational process; integration of science and practice; scientific and pedagogical development and professional internships of specialists; studying best practices in organizing distance learning; developing the new methods of conducting distance lecture courses.

In addition to usual internship activities, some internship programs may include: participation in a practical conference, collaboration within a research project, writing a scientific publication, reading lectures and conducting seminars for local students, participation in a scientific round table, being engaged in preparation international grant projects and programs, involvement in peer-review groups and editorial boards, participation in international master-classes, workshops, scientific festivals, and other extracurricular activities.

Acultural program traditionally includes excursions to natural and cultural sites, visiting exhibitions, various entertaining institutions, etc. Depending on internship duration and transfer-accommodationresidence conditions the pricing policies are sometimes significantly different. According to the teachers' survey results, the decisive factors for choosing an internship place may include not only the specific scientific reasons but also the tourist attractiveness of a country, a city, an institution. This means that Ukraine has significant chances to be attractive for the scientific travellers in this aspect as well.

The most important constituent part of Ukraine's tourist potential is its rich historical and cultural heritage counting about 78 thousand archeological sites, 15 thousand historical sites, 373 thousand site of architecture and 80 thousand items of monumental art, including the monastery and garden-park architectural ensembles. Besides, seven objects from the UNESCO World Heritage List are also located in Ukraine [16]. These are the reasons why so many researchers from other countries are interested in visiting our places. In addition, Ukraine has rich natural environment, favorable climate, and affordable prices. 


\section{Conclusions}

Every year numerous Ukrainian universities and research centers host plenty of international conferences and congresses in various fields of science, and scientists from different countries are always invited to participate. However, according to a statistical analysis, the number of foreign participants (including correspondence participation in these forums) does not reach $5 \%$, and even less scientific tourists are willing to visit Ukraine personally for educational purposes.

Among the main reasons for this unfavourable situation are economic, political, and social instability. Many foreign scientists can be attracted by the theoretical scientific achievements of the Ukrainian researchers or may get interested with visiting various natural objects and places which are curious from the historical point of view. But obsolete equipment, imperfect infrastructure, low level of the tourist services as well as other disappointing factors can often frustrate potential tourists-scientists. We also note the complete absence of the brands like «science in Ukraine» and "education in Ukraine». Nevertheless, there are reasons to believe that Ukraine still has significant potential in the field of scientific tourism. Realization of this potential presumes using a systematic approach to the problem of the Ukrainian scientific tourism improvement, the development of an appropriate strategy for its development, based on the combined efforts of both scientists and practitioners who represent the spheres of education, science, tourism and related industries.

A well-known Ukrainian researcher M. Khaliavka has recently analyzed the history and the presentday trends of the scientific tourism development in Ukraine. The author has come to the conclusion that the existing resource basis, embodied in the natural and anthropogenic objects, gives all groundings for quick and successful development of this industry. Indeed, in Ukraine, each region has a significant scientific and tourist potential. For example, Dnipropetrovsk region can offer scientific tours of the natural science directions (geology, mineralogy, hydrology, geo-botany, ecology, historical geography, etc.). Lviv region is rich in objects that may be of great interest to religious edifices researchers. Vinnitsa, Zhytomyr, Kharkiv and all other regions have significant historical and cultural potential (architecture, archeology, history, monumental art and others) [17].

\section{Scientific novelty}

Creation of the scientific tourism enterprises network in the majority of Ukrainian cities can promote establishing friendly relationships with other countries and formation of effective cooperation in many other related sectors of economy. The scientific tourism development will positively influence the quality of the local people's life by making it possible to create new jobs in the tourism sector, which helps to reduce the unemployment rate in the country.

In general, the scientific tourism is an important component of the global intercultural cooperation. Therefore the value of this phenomenon and its contribution to the European education system can not be underestimated. Indeed, the organization of scientific tourism in Ukraine will be able to increase the attractiveness of Ukrainian universities for foreign students. The youth from Asian, Arabic and African countries may get interested in Ukrainian education. Nowadays the students from these regions represent a huge target segment that can be actively involved in the economy, education, socio-cultural processes. In addition, the system of higher education in Ukraine has great potential for the tourist business as well. It can be successfully used as an element of scientific tourism industry attracting the flows of scientists, teachers, and students from foreign countries.

For a quick and adequate response to the worldwide trends of the student youth migration, as well as for attracting the international scientific communities' representatives, a number of active steps and organizational measures are required. The main task is in elaboration the advertising events and promoting activities able to represent our scientific and educational achievements to the world's scientific community. It is also necessary to develop the tourism infrastructure and encourage the institutes', universities', and research centers' activities which are aimed at the international scientific and educational cooperation, especially at the scientific tourism industry development. Therefore, we suggest the further research areas to include analyzing the Ukrainian universities' capabilities in the field of providing internship programs for teachers and scholars from the European Union countries. 


\section{References [Jimepamypa]}

1. Association Agreement between the European Union and the European Atomic Energy Community and their member states, of the one part, and Ukraine, of the other part (2014). Official Journal of the European Union. L 311/1. 31.10.2014. Brussels.

2. Ivanov S., Tashlai I. (2014). Educational tourism - the case of Eastern European students: driving forces, consequences, and effects on the tourism industry. Tourism Today, 14, 37-54.

3. Brent W.R., Carr N., Cooper, C.P. (2003). Managing educational tourism. London : Cromwell Press.

4. Ageeva O.A. (2011). Management of the Educational Tourism in Russia. Innovations and Investments, 19(3), $201-205$.

5. Laarman J.G., Perdue R.R. (1980). Tropical science and tourism: The case of OTS in Costa Rica. Tourism Management, 10 (1), 29-38.

6. Holbrook M.B., Hirschman E.C. (1982). The Experiential Aspects of Consumption: Consumer Fantasies, Feelings, and Fan. The Journal of Consumer Research, 9, 132-140.

7. Kujawinski P. (2018). Colliders, Sundials and Wonder: When Science Is Your Destination. The New York Times, May 28, 2018.

8. Ilyina L., Mieczkowski Z. (1992) Developing Scientific Tourism in Russia. Tourism Management, 13(3), $327-331$.

9. Laing J. H. (2010). Science tourism: exploring the potential for astrobiology funding and outreach. Evolution and Life: Surviving Catastrophes and Extremes on Earth and Beyond. Paper presented at Astrobiology Science Conference, April 26-20, 2010, League City, Texas, 5047-5048.

10. Pichlerová M. (2007). Scientific Tourism Development in the Slovak Carpathians. Ecotourism and sustainable development in the Carpathians. Paper presented at the International Conference, October 10-12, 2010, Carpathian Biosphere Reserve, Rakhiv, Ukraine, 251-254.

11. Molokacova L., Molokac S. (2011). Scientific tourism: tourism in science or science in tourism? Acta Geoturistica, 2(1), 41-45.

12. Bourlon F., Torres R. (2016). Scientific tourism, a tool for tourism development in Patagonia. LabEx ITEM Innovation and Mountain territories. Paper presented at the Second International Winter School, 27-29 January, 2016, Autrans (France).

13. Volovyk P.M. (2010). Probability Theory and Mathematical Statistics in Pedagogy. Khmelnytskyi, 250 p. [In Ukrainian]. [Воловик П.М. Теорія імовірностей і математична статистика в педагогіці. НАПН України, Ін-т пед. освіти і освіти дорослих / за ред. В.С. Береки. - Хмельницький, 2010. 250 с.]

14. Glass G.V., Stanley J.C. (1970). Statistical Methods in Education and Psychology. New Jersey : Prentice-Hall, Inc.

15. The Law of Ukraine «On Higher Education», 1556-VII. (2014). Verkhovna Rada of Ukraine Secretariat. URL : https:// zakon.rada.gov.ua/laws/show/1556-18 [In Ukrainian].

[Закон України «Про вищу освіту» (2014). Відомості Верховної Ради України. 1556-VII.]

16. UA-Travels (2017). Visit UNESCO World's Heritage Objects in Ukraine. URL : http://ua-travels.in.ua/2017/10/17/uatravels-vidviduyemo-svitovu-spadshhinu-yunesko-v-ukra\%D1\%97ni/

17. Khaliavka M. (2016). History and Development of Scientific Tourism in Ukraine. East-European Historical Bulletin, Iss. 1, 100-105 [In Ukrainian].

[Халявка М. Історія та стан розвитку наукового туризму в Україні / М. Халявка // Східноєвропейський історичний вісник. 2016. Вип. 1. С. 100-105.]

The article was received on 20.08.2019 